\title{
Association study between BGLAP RS1800247-polymorphic variant and type 2 diabetes mellitus development among hypertensive and non-hypertensive Ukrainians
}

\author{
Ya. D. Chumachenko® $* 1, D$, M. O. Kyrychenko ${ }^{1, B}$, D. M. Ramazanova ${ }^{(1), B}$, \\ M. V. Smiianova ${ }^{3, C}$, V. Yu. Harbuzova ${ }^{1, A, E}$, , O. V. Ataman ${ }^{11, F}$ \\ ${ }^{1}$ Medical Institute of the Sumy State University, Ukraine, ${ }^{2}$ Kyiv Regional Perinatal Center, Ukraine, ${ }^{3}$ Medical Center "Medeya”, Sumy, Ukraine
}

A - research concept and design; B - collection and/or assembly of data; C - data analysis and interpretation; D - writing the article; $\mathrm{E}$ - critical revision of the article; $\mathrm{F}$ - final approval of the article

Key words: type 2 diabetes mellitus,

hypertension, osteocalcin, single nucleotide polymorphism, TT-homozygote, TC-heterozygote, CC-homozygote.

Zaporozhye medical journal 2021; 23 (3), 338-342

*E-mail:

yaroslavus.dm@ gmail.com
The risk of type 2 diabetes mellitus (T2DM) development depends on a hereditary predisposition. According to the current data, bone tissue enhances insulin gene expression in pancreatic $\beta$-cells as well as increases insulin sensitivity of adipocytes, myocytes and hepatocytes through the secretion of undercarboxylated osteocalcin (unOCN).

The aim. To analyze the relation between rs1800247 SNP and T2DM occurrence depending on the arterial hypertension (AH) presence, as well as association between rs 1800247 and systolic, diastolic, pulse, mean blood pressure among patients with T2DM.

Materials and methods. This study included 153 patients with diagnosed T2DM and 311 individuals without any carbohydrate metabolism disorders. Polymerase chain reaction-restriction fragment length polymorphism analysis (PCR-RFLP) was used for $B G L A P$ rs1800247-genotyping. Logistic regression with interaction term "genotype $\times$ AH" was used to estimate the association between BGLAP rs1800247-genotypes and T2DM development in dominant, recessive, over-dominant and additive models of inheritance. Linear regression was performed to examine the influence of minor C-allele on the arterial blood pressure. Lipid profile characteristics of T2DM patients were stratified by rs1800247-genotype using ANOVA with Bonferroni post hoc test. All calculations were performed using Statistical Package for the Social Sciences software (SPSS, version 22.0, Chicago, IL, USA). A value of $P<0.05$ was considered as significant.

Results. No association was found between rs1800247 single nucleotide polymorphism and T2DM development neither in $\mathrm{AH}$ patients, nor in subjects without $\mathrm{AH}\left(\mathrm{P}_{\mathrm{a}}^{\mathrm{int} b}>0.05\right)$. There was no impact of rs 1800247 genotypes on systolic, diastolic, pulse and mean blood pressure among patients with T2DM $(P>0.05)$. It was showed that T2DM non-hypertensive CC-carriers had significantly lower levels of total cholesterol $(P=0.012)$ and LDL cholesterol $(P=0.04)$, but higher concentration of HDL cholesterol $(P=0.015)$ compared to the TT-genotype.

Conclusions. It was showed that CC-carriers had more favorable parameters of lipid metabolism among T2DM non-hypertensive Ukrainians. However, there was no association between rs1800247 SNP and T2DM development as well as blood pressure parameters.
Киючові слова: цукровий діабет 2 типу, артеріальна гіпертензія, остеокальцин, ОАНОНУКмеОтИАниЙ поліморфізм, ТТ-домінантна гомозигота, ТС-гетерозигота, СС-рецесивна гомозигота.

Запорізький медичний журнал. 2021. T. 23, № 3(126). C. 338-342

\section{Вивчення зв'язку між RS1800247-поліморфним варіантом гена BGLAP і розвитком цукрового діабету 2 типу серед українців з артеріальною гіпертензією та нормальним артеріальним тиском}

\section{Я. А. Чумаченко, М. О. Кириченко, А. М. Рамазанова, М. В. Сміянова, В. Ю. Гарбузова, О. В. Атаман}

Ризик виникнення цукрового діабету 2 типу (ЦД2) залежить від генетичної схильності. За сучасними даними, кісткова тканина підвищує експресію гена інсуліну $\beta$-клітинами підшлункової залози, а також збільшує чутливість адипоцитів, міоцитів і гепатоцитів до інсуліну шляхом продукування декарбоксильованого остеокальцину (unOCN).

Мета роботи - проаналізувати зв'язок між rs1800247-однонуклеотидним поліморфізмом і виникненням ЦД2 залежно від наявності артеріальної гіпертензії (АГ), а також зв'язок між rs 1800247 і систолічним, діастолічним, пульсовим, середнім кров'яним тиском в осіб із ЦД2.

Матеріали та методи. У дослідження залучили 153 пацієнтів з діагностованим ЦД2 і 311 осіб без будь-яких порушень вуглеводного обміну. Генотипування осіб за rs1800247-поліморфізмом гена BGLAP виконали за допомогою полімеразної ланцюгової реакції з аналізом довжини рестрикційних фрагментів (PCR-RFLP). Для оцінювання зв'язку між генотипами за rs1800247-поліморфрізмом гена BGLAP і розвитком ЦД2 застосували логістичну регресію (враховуючи незалежну змінну «генотип × АГ») у межах домінантної, рецесивної, наддомінантної та адитивної моделей спадкування.

Для дослідження впливу мінорного С-алеля на рівень артеріального тиску використали метод лінійної регресії. Показники ліпідного обміну в пацієнтів із ЦД2 залежно від rs1800247-генотипу порівнювали за допомогою однофакторного дисперсійного аналізу та тесту Бонферроні. Усі розрахунки виконали, використовуючи програму для статистичного опрацювання даних SPSS 22.0. Значення $\mathrm{p}<0,05$ свідчило про статистичну значущість результатів.

Результати. Встановили відсутність зв'язку між rs1800247-однонуклеотидним поліморфізмом і розвитком ЦД2 і в осіб з АГ, і в обстежених із нормальним артеріальним тиском ( $\left.p_{a}^{\text {int b }}>0,05\right)$. Вплив генотипів за rs1800247-поліморфізмом на рівні систолічного, діастолічного, пульсового та середнього тиску в осіб із ЦД2 відсутній ( $p>0,05)$. Однак носії СС-генотипу у 
групі хворих на ЦД2 без АГ мають істотно нижчий рівень загального холестеролу $(p=0,012)$, ЛПНЩ $(p=0,04)$ і вищий рівень ЛПВЩ ( $p=0,015)$ порівняно з ТТ-генотипом.

Висновки. Виявили, що носії СС-генотипу мають сприятливіші показники ліпідного метаболізму серед українців із ЦД2 та без АГ. Але відсутній зв'язок між rs1800247-однонуклеотидним поліморфізмом, виникненням ЦД2 і показниками артеріального тиску.

\section{Изучение связи между RS1800247-полиморфным вариантом гена BGLAP и развитием сахарного диабета 2 типа среди украинцев с артериальной гипертензией и нормальным артериальным давлением}

\section{Я. А. Чумаченко, Н. А. Кириченко, А. М. Рамазанова, М. В. Смеянова, В. Ю. Гарбузова, А. В. Атаман}

Риск возникновения сахарного диабета 2 типа (СД2) зависит от генетической предрасположенности. В соответствии с современными данными, костная ткань увеличивает экспрессию гена инсулина $\beta$-клетками поджелудочной железы, а также повышает чувствительность адипоцитов, миоцитов и гепатоцитов к инсулину путём продукции декарбоксилированного остеокальцина (unOCN).

Цель работы - проанализировать связь между rs1800247-однонуклеотидным полиморфизмом и возникновением СД2 в зависимости от наличия артериальной гипертензии (АГ), а также связь между rs 1800247 и систолическим, диастолическим, пульсовым, средним кровяным давлением у пациентов с СД2.

Материалы и методы. В исследование включили 153 пациента с диагностированным СД2 и 311 лиц без каких-либо нарушений углеводного обмена. Генотипирование участников исследования по rs1800247-полиморфизмом гена BGLAP проведено при помощи полимеразной цепной реакции с анализом длины рестрикционных фррагментов (PCR-RFLP). Для оценки связи между rs1800247-полиморфизмом гена BGLAP и развитием СД2 использована логистическая регрессия (с учётом независимой переменной «генотип × АГ») в пределах доминантной, рецессивной, сверхдоминантной и аддитивной моделей наследования.

Для исследования влияния минорного С-аллеля на уровень артериального давления использован метод линейной регрессии. Показатели липидного обмена у пациентов с СД2 в зависимости от rs1800247-генотипа сравнивали при помощи однофакторного дисперсионного анализа и теста Бонферрони. Все расчёты проведены с использованием программы для статистической обработки данных SPSS 22.0. Значение $p<0,05$ свидетельствовало о статистической значимости результатов.

Результаты. Установлено отсутствие связи между rs1800247-однонуклеотидным полиморфизмом и развитием СД2 среди лиц и с АГ, и с нормальным артериальным давлением ( $p_{a}^{\text {int b }>0,05) . ~ В л и я н и е ~ г е н о т и п о в ~ п о ~ r s 1800247-п о л и м о р ф и з м у ~ н а ~}$ уровни систолического, диастолического, пульсового и среднего давления у лиц с СД2 отсутствует (p > 0,05). Однако носители СС-генотипа в группе больных СД2 без АГ имеют значительно более низкий уровень общего холестерола $(p=0,012)$, ЛПНП ( $p=0,04)$ и более высокий уровень ЛПВП $(p=0,015)$ в сравнении с ТТ-генотипом.

Выводы. Установлено, что носители СС-генотипа имеют более благоприятные показатели липидного метаболизма среди украинцев с СД2 и без АГ. Однако отсутствует связь между rs1800247-однонуклеотидным полиморфизмом и возникновением СД2, а также показателями артериального давления.

Nowadays it is known about at least two proteins of bone tissue that could influence on systemic energy metabolism. The first one is undercarboxylated osteocalcin (unOCN), which directly stimulates insulin production in pancreatic $\beta$-cells and increases peripheral tissue sensitivity to this hormone. The second one, osteotesticular tyrosine phosphatase (OST-PTP), regulates OCN gene expression in accordance with metabolic requirements of the bone tissue [1]. Bone reparation was the priority process of energy substrate distribution in animals, as the integrity of bones was vitally needed. Thus, active OST-PTP dephosphorylates the $\beta$-subunits of insulin receptor that leads to inhibition of metabolic and proliferative effects of this hormone. The consequence is the decreased rate of Runx 2, which is the crucial transcription factor for OCN gene expression. Temporary reducing of unOCN level in systemic circulation leads to hypoinsulinaemia, as well as decreased adipose, muscle and liver tissue sensitivity to insulin. As the result, more glucose reaches a bone cell that is important for synthesis and resorption of bone tissue [1-3].

The involvement of unOCN in the energy metabolism was confirmed in experimental and clinical studies. It is known that OCN gene-knockout mouse $\left(\mathrm{Bglap}^{-/}\right)$have increased bone tissue formation without the influence on bone resorption. In the same time their phenotype was opposite to OST-PTP gene-knockout mouse $\left(P t p r^{\prime}\right)$, which showed an impaired glucose tolerance and overweight $[4,5]$. unOCN binds to specific GPRC6A receptors and enhances insulin and adiponectin expression, as well as $\beta$-cell proliferation [6].

Meta-analysis indicates the presence of reverse correlation between $\mathrm{OCN}$ plasma concentration and insulin, fasting glucose and glycated hemoglobin in patients with type 2 diabetes mellitus (T2DM) [7]. Moreover, rs1800247-single nucleotide polymorphism (SNP) of BGLAP gene was associated with decreased risk of arterial hypertension $(\mathrm{AH})$ and lower diastolic blood pressure [8].

\section{Aim}

Therefore, the aim of this study was to analyze the relation between rs1800247 SNP and T2DM occurrence depending on the $\mathrm{AH}$ presence, as well as association between rs1800247 and systolic, diastolic, pulse, mean blood pressure among patients with T2DM.
Ключевые слова:

сахарный Аиабет 2 типа, артериальная гипертензия, остеокальцин, оАнонуклеотиАНЫЙ полиморфизм, ТТ-Аоминантная гомозигота, ТС-гетерозигота, СС-рецессивная гомозигота. медицинский журнал. 2021. T. 23, № 3(126). C. $338-342$ 
Table 1. Characteristics of the study population

\begin{tabular}{|c|c|c|c|}
\hline \multicolumn{4}{|l|}{ With AH } \\
\hline Parameters, units & T2DM (n = 107) & Control $(n=156)$ & $\mathbf{P}$ \\
\hline Age, years & $64.49 \pm 8.11$ & $69.53 \pm 11.31$ & $<0.001$ \\
\hline Sex, female/male & $56 / 52$ & $101 / 55$ & 0.036 \\
\hline Body mass index, $\mathrm{kg} / \mathrm{m}^{2}$ & $29.7 \pm 4.98$ & $27.62 \pm 4.69$ & 0.001 \\
\hline Current smokers, $n(\%)$ & $36(33.3)$ & $48(30.8)$ & 0.66 \\
\hline Fasting glucose, mmol/L & $10.35 \pm 3.77$ & $5.22 \pm 0.68$ & $<0.001$ \\
\hline Total cholesterol, $\mathrm{mmol} / \mathrm{L}$ & $5.24 \pm 1.18$ & $4.56 \pm 1.26$ & $<0.001$ \\
\hline HDL cholesterol, mmol/L & $0.94 \pm 0.28$ & $1.09 \pm 0.28$ & $<0.001$ \\
\hline LDL cholesterol, mmol/L & $3.36 \pm 1.16$ & $2.8 \pm 1.22$ & 0.003 \\
\hline Triglyceride, $\mathrm{mmol} / \mathrm{L}$ & $1.76 \pm 0.66$ & $1.44 \pm 0.65$ & 0.002 \\
\hline Systolic BP, mmHg & $151.71 \pm 14.78$ & $174.46 \pm 22.69$ & $<0.001$ \\
\hline Diastolic BP, mmHg & $92.31 \pm 8.6$ & $97.05 \pm 13.89$ & 0.002 \\
\hline Pulse BP, mmHg & $59.4 \pm 13.43$ & $77.4 \pm 19.32$ & $<0.001$ \\
\hline Mean BP, mmHg & $112.12 \pm 9.06$ & $122.85 \pm 14.74$ & $<0.001$ \\
\hline \multicolumn{4}{|l|}{ Without AH } \\
\hline Parameter, units & T2DM (n = 46) & Control $(n=155)$ & $\mathbf{P}$ \\
\hline Age, years & $65.26 \pm 8.49$ & $61.75 \pm 12.61$ & 0.078 \\
\hline Sex, female/male & $23 / 23$ & $51 / 104$ & 0.035 \\
\hline Body mass index, $\mathrm{kg} / \mathrm{m}^{2}$ & $28.35 \pm 4.74$ & $27.38 \pm 4.72$ & 0.222 \\
\hline Current smokers, $n(\%)$ & $14(30.4)$ & $43(27.7)$ & 0.722 \\
\hline Fasting glucose, $\mathrm{mmol} / \mathrm{L}$ & $9.86 \pm 2.57$ & $5.23 \pm 0.73$ & $<0.001$ \\
\hline Total cholesterol, mmol/L & $5.65 \pm 1.35$ & $4.14 \pm 1.15$ & $<0.001$ \\
\hline HDL cholesterol, mmol/L & $0.96 \pm 0.31$ & $1.09 \pm 0.19$ & 0.038 \\
\hline LDL cholesterol, mmol/L & $3.54 \pm 1.39$ & $2.48 \pm 1.12$ & 0.001 \\
\hline Triglyceride, $\mathrm{mmol} / \mathrm{L}$ & $2.22 \pm 2.49$ & $1.25 \pm 0.51$ & 0.051 \\
\hline Systolic BP, mmHg & $126.09 \pm 8.02$ & $126.84 \pm 11.09$ & 0.67 \\
\hline Diastolic BP, mmHg & $79.67 \pm 4.76$ & $79.58 \pm 7.05$ & 0.933 \\
\hline Pulse BP, mmHg & $46.41 \pm 6.02$ & $47.26 \pm 9.01$ & 0.551 \\
\hline Mean BPs, mmHg & $95.14 \pm 5.34$ & $95.33 \pm 7.49$ & 0.874 \\
\hline
\end{tabular}

AH: arterial hypertension; T2DM: type 2 diabetes mellitus; HDL: high density lipoproteins; LDL: low density lipoproteins; BP: blood pressure.

\section{Materials and methods}

Study population and genotyping. This study included 153 patients ( 75 females and 78 males; mean age $[ \pm S D]$ $64.67 \pm 8.2$ year) with diagnosed T2DM and 311 individuals (106 females and 205 males; mean age $65.65 \pm 12.58$ year) without any carbohydrate metabolism disorders. Final T2DM diagnosis was determined in the presence of specific clinical manifestations (polydipsia, polyuria, polyphagia and weight loss), fasting glucose level and glucose tolerance test results according to the World Health Organization criteria (WHO, 1999).

Relatively healthy subjects without any carbohydrate metabolism disorders (which was confirmed by a fasting plasma glucose level less than $5.6 \mathrm{mmol} / \mathrm{L}$ and a $75 \mathrm{~g}$ oral glucose tolerance test result less than $7.8 \mathrm{mmol} / \mathrm{L}$ ) and negative family history of diabetes were enrolled in the control group. All the examined individuals were selected from hospital records in the 5th Sumy Clinical Hospital and Sumy Regional Diagnostic Center between 2011-2019. AH was diagnosed in 107 T2DM patients and 156 control subjects with systolic blood pressure higher than $140 \mathrm{mmHg}$ and/or diastolic blood pressure higher than $90 \mathrm{mmHg}$ and no antihypertensive therapy (according to the WHO, 1999). Polymerase chain reaction-restriction fragment length polymorphism analysis (PCR-RFLP) was used for BGLAP rs1800247-genotyping. Full information about genotyping protocol was presented in our previous research [9].

The study design complies with the Declaration of Helsinki and was approved by the Ethic Committee of Medical Institute of Sumy State University and the Ethic Committee of Medical Institute of Sumy State University (number 4/02.18.09). A written informed consent was obtained from all participants.

Statistical analysis. Continuous variables were presented as the mean $\pm S D$, categorical - as absolute and percentage values. Chi square $\left(X^{2}\right)$ test was used for comparing the categorical variables. Two-tailed Student's t-test was used to compare the mean values of two groups (with preliminary verification of the data distribution for normality through the Shapiro-Wilk test). The mean values of three groups were compared using ANOVA with further Bonferroni post hoc test. Logistic regression with interaction term "genotype $\times \mathrm{AH}$ " was used for the association analysis between four models of inheritance: dominant, recessive, over-dominant and additive.

The adjustment for age, sex, smoking and body mass index (BMI) was used to exclude the influence of other T2DM risk factors. Bonferroni correction was applied for accurate results. The impact of rs $1800247-\mathrm{C}$ minor allele on systolic, diastolic, pulse and mean arterial blood pressure among diabetic patients was estimated via linear regression. All calculations were performed using Statistical Package for the Social Sciences software (SPSS, version 22.0, Chicago, IL, USA). A value of $\mathrm{P}<0.05$ was considered as significant.

\section{Results}

The clinical characteristics of compared groups are shown in Table 1. Statistically significant differences in age, sex, BMI, fasting glucose, lipid profile and blood pressure parameters $(P<0.05)$, but not among smokers $(P=0.66)$, was found in groups with $\mathrm{AH}$. In contrast, T2DM patients and controls without $\mathrm{AH}$ were comparable in age, BMI, smoking status, triglyceride concentration and blood pressure parameters $(P>0.05)$, but not in sex, fasting glucose levels, total cholesterol, high density lipoprotein (HDL) cholesterol and low density lipoprotein (LDL) cholesterol concentrations $(\mathrm{P}<0.05)$

Logistic regression with interaction term was used to study the influence of rs1800247 genotypes on the T2DM development There was no statistically significant associations neither in $\mathrm{AH}$ patients, nor in non- $\mathrm{AH}$ individuals in all models of inheritance (Table 2).

Then we performed the linear regression models to compare the rs 1800247 genotype impact on the arterial blood pressure values. No significant differences were found for systolic, diastolic, pulse and mean arterial blood pressure among T2DM patients (Table 3).

Table 4 indicates the parameters of lipid profile in T2DM patients with and without AH stratified by rs 1800247 genotypes. Statistically significant differences were found between TT and CC carriers in total cholesterol $(P=0.012)$, HDL cholesterol $(P=0.015)$ and LDL cholesterol $(P=0.04)$ concentrations among T2DM individuals without $\mathrm{AH}$. 
Table 2. Association analysis between BGLAP rs 1800247 and T2DM development among AH and non-AH individuals

\begin{tabular}{|c|c|c|c|c|c|c|c|c|c|}
\hline Regression model $^{1}$ & Covariate & $P_{c}$ & $\mathrm{OR}_{\mathrm{c}}(95 \% \mathrm{Cl})$ & $P_{c}$ int & $P_{a}$ & $\mathrm{OR}_{\mathrm{a}}(95 \% \mathrm{Cl})$ & $\mathbf{P}_{a}^{\text {int }}$ & $P_{a}^{b}$ & $P$ int b \\
\hline \multirow[t]{2}{*}{ Dominant } & $\mathrm{TC}+\mathrm{CC}$ vs TT & 0.268 & $0.748(0.448-1.25)$ & 0.976 & 0.199 & $0.708(0.417-1.200)$ & 0.754 & 0.796 & 1 \\
\hline & & 0.429 & $0.758(0.382-1.506)$ & & 0.565 & $0.814(0.405-1.639)$ & & 1 & \\
\hline \multirow[t]{2}{*}{ Recessive } & CC vs TT+TC & 0.681 & $1.264(0.413-3.873)$ & 0.412 & 0.674 & $1.279(0.406-4.036)$ & 0.367 & 1 & 1 \\
\hline & & 0.11 & $2.433(0.818-7.242)$ & & 0.082 & $2.662(0.883-8.027)$ & & 0.382 & \\
\hline \multirow[t]{2}{*}{ Over-dominant } & CT vs $\mathrm{TT}+\mathrm{CC}$ & 0.183 & $0.696(0.408-1.187)$ & 0.504 & 0.131 & $0.655(0.378-1.134)$ & 0.653 & 0.524 & 1 \\
\hline & & 0.084 & $0.505(0.233-1.095)$ & & 0.109 & $0.525(0.239-1.156)$ & & 0.436 & \\
\hline \multirow[t]{4}{*}{ Additive } & CT vs TT & 0.199 & $0.702(0.409-1.205)$ & 0.622 & 0.149 & $0.664(0.381-1.157)$ & 0.779 & 0.596 & 1 \\
\hline & & 0.14 & $0.552(0.25-1.215)$ & & 0.181 & $0.577(0.258-1.291)$ & & 0.724 & \\
\hline & CC vs TT & 0.841 & $1.123(0.361-3.387)$ & 0.468 & 0.833 & $1.135(0.351-3.673)$ & 0.363 & 1 & 1 \\
\hline & & 0.215 & $2.022(0.665-6.151)$ & & 0.127 & $2.422(0.778-7.539)$ & & 0.508 & \\
\hline
\end{tabular}

1: Upper row shows the results for individuals with $\mathrm{AH}$ and lower row - for those without AH; Pc: crude value; Pcint: crude value for interactive term; Pa: value adjusted for age, sex, smoking status, and body mass index; Paint: value adjusted for age, sex, smoking status, and body mass index for interaction term; Pab: value adjusted for Bonferroni correction; Paint b: value adjusted for Bonferroni correction for interaction term; T2DM: type 2 diabetes mellitus; AH: arterial hypertension, T: homozygous dominant, TC: heterozygous, cC: homozygous recessive.

\section{Discussion}

It is known that T2DM patients have lower carboxylated osteocalcin ( $\mathrm{COCN})$ and unOCN concentrations than relatively healthy subjects $[10,11]$. The meta-analysis showed significantly decreased baseline serum total OCN in T2DM compared with non-T2DM subjects. Moreover, a unit elevation in serum total $\mathrm{OCN}$ was correlated with a mean increase in $\mathrm{HOMA}-\mathrm{B}$, as well as mean reduction in $\mathrm{HbA1c}$, fasting plasma glucose, HOMA-IR and BMI [12].

In this study, we continued to study the association between BGLAP rs 1800247 SNP and T2DM development among Ukrainians. The lack of studied correlation matches both our previous research [9] and Das et al. study, which excluded BGLAP rs1800247 SNP as a T2DM potential risk factor [13].

Cardiovascular diseases are widespread chronic complications in patients with T2DM. Animal and in vitro studies showed the protective effect of unOCN on vessels. This was explained by the enhanced expression of endothelial nitric oxide synthase (eNOS) and nitric oxide (NO) production [14]. Lower serum OCN concentration was found among hypertensive men, but not women. Moreover, serum OCN level was inversely associated with systolic blood pressure in Chinese men, but not women [15].

Another study showed that BGLAP rs 1800247 was associated with lower risk of $\mathrm{AH}$ and diastolic blood pressure in Chinese population [8]. In contrast, our study indicates no relation between BGLAP rs1800247 and blood pressure level among T2DM Ukrainians that can be explained by ethnic differences. Despite this, in present study, we showed that T2DM non-hypertensive CC-carriers had significantly lower levels of total cholesterol and LDL cholesterol, but higher concentration of HDL cholesterol compared to those in the TT-genotype. The results obtained may indicate more favorable conditions for the lipid metabolism in CC-homozyguous of the examined groups among Ukrainians.

\section{Conclusions}

1. Non-hypertensive T2DM CC-carriers had significantly lower levels of total cholesterol $(P=0.012)$ and LDL cholesterol $(P=0.04)$, but higher concentration of $\mathrm{HDL}$ cholesterol $(P=0.015)$ compared to the TT-genotype in Ukrainian population.
Table 3. Association analysis between BGLAP rs1800247 and blood pressure value among T2DM patients

\begin{tabular}{|c|c|c|c|}
\hline Regression model & B & $\mathbf{P}$ & $r^{2}$ \\
\hline \multicolumn{4}{|l|}{ Systolic blood pressure } \\
\hline TC vs TT & 2.363 & 0.476 & 0.01 \\
\hline CC vs TT & -4.596 & 0.396 & \\
\hline Constant & 143.762 & $<0.001$ & \\
\hline \multicolumn{4}{|c|}{ Diastolic blood pressure } \\
\hline TC vs TT & -0.239 & 0.895 & $<0.001$ \\
\hline CC vs TT & -0.281 & 0.925 & \\
\hline Constant & 88.614 & $<0.001$ & \\
\hline \multicolumn{4}{|l|}{ Pulse blood pressure } \\
\hline TC vs TT & 2.601 & 0.291 & 0.018 \\
\hline CC vs TT & -4.315 & 0.284 & \\
\hline Constant & 55.149 & $<0.001$ & \\
\hline \multicolumn{4}{|l|}{ Mean blood pressure } \\
\hline TC vs TT & 0.625 & 0.768 & 0.003 \\
\hline CC vs TT & -1.722 & 0.62 & \\
\hline Constant & 107 & $<0.001$ & \\
\hline
\end{tabular}

B: regression coefficient; r2: r-squared value; T2DM: type 2 diabetes mellitus; T: homozygous dominant; TC: heterozygous; CC: homozygous recessive.

Table 4. Lipid profile in T2DM patients with and without $\mathrm{AH}$ stratified by BGLAP rs1800247 genotypes

\begin{tabular}{|c|c|c|c|c|c|}
\hline \multicolumn{6}{|l|}{ With AH } \\
\hline \multirow[t]{2}{*}{ Parameters, units } & \multicolumn{3}{|l|}{ Genotype } & \multirow[t]{2}{*}{$F$} & \multirow[t]{2}{*}{$P$} \\
\hline & $\mathrm{TT}(\mathrm{n}=71)$ & $\mathrm{TC}(\mathrm{n}=30)$ & $C C(n=6)$ & & \\
\hline Total cholesterol, mmol/L & $5.26 \pm 1.22$ & $5.19 \pm 1.11$ & $5.14 \pm 1.28$ & 0.057 & 0.945 \\
\hline $\mathrm{HDL}$ cholesterol, mmol/L & $0.96 \pm 0.28$ & $0.86 \pm 0.27$ & $1.05 \pm 0.22$ & 2.004 & 0.14 \\
\hline LDL cholesterol, mmol/L & $3.33 \pm 1.17$ & $3.42 \pm 1.14$ & $3.36 \pm 1.22$ & 0.065 & 0.937 \\
\hline Triglyceride, $\mathrm{mmol} / \mathrm{L}$ & $1.73 \pm 0.66$ & $1.88 \pm 0.65$ & $1.58 \pm 0.75$ & 0.763 & 0.469 \\
\hline \multicolumn{6}{|l|}{ Without AH } \\
\hline \multirow[t]{2}{*}{ Parameters, units } & \multicolumn{3}{|l|}{ Genotype } & \multirow[t]{2}{*}{$\mathbf{F}$} & \multirow[t]{2}{*}{$P$} \\
\hline & $\mathrm{TT}(\mathrm{n}=30)$ & $\mathrm{TC}(\mathrm{n}=10)$ & $C C(n=6)$ & & \\
\hline Total cholesterol, $\mathrm{mmol} / \mathrm{L}$ & $5.95 \pm 1.32$ & $5.04 \pm 1.23$ & $4.27 \pm 0.54$ & 5.666 & $0.007^{1}$ \\
\hline $\mathrm{HDL}$ cholesterol, $\mathrm{mmol} / \mathrm{L}$ & $0.94 \pm 0.26$ & $1.01 \pm 0.39$ & $1.32 \pm 0.12$ & 4.368 & $0.019^{2}$ \\
\hline LDL cholesterol, $\mathrm{mmol} / \mathrm{L}$ & $3.8 \pm 1.41$ & $2.85 \pm 1.07$ & $2.33 \pm 0.63$ & 4.53 & $0.016^{3}$ \\
\hline Triglyceride, $\mathrm{mmol} / \mathrm{L}$ & $2.43 \pm 3.04$ & $1.88 \pm 0.74$ & $1.68 \pm 0.62$ & 0.332 & 0.719 \\
\hline
\end{tabular}

AH: arterial hypertension; T2DM: type 2 diabetes mellitus; HDL: high density lipoproteins; LDL: low density lipoproteins; 1: significant difference between the TT and CC genotypes $(P=0.012)$ by Bonferroni post hoc test; 2: significant difference between the TT and CC genotypes $(P=0.015)$ by Bonferroni post hoc test; 3: significant difference between the TT and CC genotypes ( $P=0.04)$ by Bonferroni post hoc test; TT: homozygous dominant, TC: heterozygous, $\mathrm{CC}$ : homozygous recessive. 
2. No association was found between rs 1800247 SNP and T2DM development among hypertensive Ukrainians $\left(P_{a}\right.$ int $\left.>0.05\right)$.

3. No association was found between rs 1800247 SNP and T2DM development among non-hypertensive Ukrainians $\left(P_{a}^{\text {int b }}>0.05\right)$.

4. There was no relation between rs1800247 SNP and blood pressure parameters (systolic, diastolic, pulse and mean blood pressure) among T2DM Ukrainians $(P>0.05)$.

Perspectives for further research. Further studies with extended groups of comparison are needed for the confirmation of results. Moreover, it will be useful to study the association between other BGLAP SNPs and T2DM and AH development.

\section{Funding}

This research was a part of the scientific project "Moleculargenetic and morphological features of lower limb tissues regeneration under conditions of chronic hyperglycemia", state registration №. 0117 U003926.

Conflicts of interest: authors have no conflict of interest to declare. Конфмікт інтересів: віАсутній.

Надійшла Ао реАакції / Received: 23.12.2020

Після Аоопрацювання / Revised: 02.03.2021

Прийнято АO Аруку / Accepted: 11.03.2021

Information about authors:

Chumachenko Ya. D., MD, PhD student, Sumy State University,

Ukraine.

ORCID ID: 0000-0002-4803-5435

Kyrychenko M. O., MD, Intern, Sumy State University, Ukraine. ORCID ID: 0000-0001-9661-3052

Ramazanova D. M., MD, Intern, obstetrician-gynecologist, Kyiv Regional Perinatal Center, Ukraine.

ORCID ID: 0000-0001-5891-3214

Smiianova M. V., Medical Director of Medical Center "Medeya", Sumy, Ukraine.

ORCID ID: 0000-0003-4336-4157

Harbuzova V. Yu., MD, PhD, DSc, Professor of the Department of Physiology and Pathophysiology with Medical Biology Course, Sumy State University, Ukraine.

ORCID ID: 0000-0001-7183-6997

Ataman 0. V., MD, PhD, DSc, Professor, Head of the Department of Physiology and Pathophysiology with Medical Biology Course, Sumy State University, Ukraine.

ORCID ID: 0000-0002-1941-740X

\section{Відомості про авторів:}

Чумаченко Я. А., аспірант, Сумський Аержавний університет, Україна.

Кириченко М. О., лікар-інтерн, Сумський Аержавний університет, Україна.

Рамазанова А. М., лікар-інтерн акушер-гінеколог, КНП КОР "Київський обласний перинатальний центр", Україна. Сміянова М. В., заступник директора з медичної частини, ТОВ "Медея", м. Суми, Україна.

Гарбузова В. Ю., А-р біол. наук, професор каф. фізіології та патофізіології з курсом медичної біології, Сумський Аержавний університет, Україна

Атаман 0. В., А-р меА. наук, професор, зав. каф. фізіології та патофізіології з курсом медичної біології, Сумський Аержавний університет, Україна.

\section{Сведения об авторах:}

Чумаченко Я. А., аспирант, Сумский государственный университет, Украина.
Кириченко Н. А., врач-интерн, Сумский государственный университет, Украина.

Рамазанова А. М., врач-интерн акушер-гинеколог,

КНП КОР "Киевский областной перинатальный центр", Украина. Смеянова М. В., зам. Аиректора по меАицинской части, 000 "Медея", г. Сумы, Украина.

Гарбузова В. Ю., А-р биол. наук, профессор каф. физиологии и патофизиологии с курсом меАицинской биологии, Сумский государственный университет, Украина.

Атаман А. В., А-р меА. наук, профессор, зав. каф. физиологии и патофизиологии с курсом медицинской биологии, Сумский государственный университет, Украина.

\section{References}

[1] Kassi, E., \& Papavassiliou, A. G. (2008). A possible role of osteocalcin in the regulation of insulin secretion: human in vivo evidence? The Journal of Endocrinology, 199(2), 151-153. https://doi.org/10.1677/ JOE-08-0294

[2] Mizokami, A., Kawakubo-Yasukochi, T., \& Hirata, M. (2017). Osteocalcin and its endocrine functions. Biochemical Pharmacology, 132, 1-8. https://doi.org/10.1016/i.bcp.2017.02.001

[3] Liu, D. M., Mosialou, I., \& Liu, J. M. (2018). Bone: Another potentia target to treat, prevent and predict diabetes. Diabetes, Obesity and Metabolism, 20(8), 1817-1828. https://doi.org/10.1111/dom.13330

[4] Fernández-Real, J. M., \& Ricart, W. (2011). Osteocalcin: a new link between bone and energy metabolism. Some evolutionary clues. Current Opinion in Clinical Nutrition and Metabolic Care, 14(4), 360-366. https://doi.org/10.1097/MCO.0b013e328346df4e

[5] Clemens, T. L., \& Karsenty, G. (2011). The osteoblast: An insulin target cell controlling glucose homeostasis. The American Society for Bone and Mineral Research, 26(4), 677-680. https://doi.org/10.1002/ibmr.321

[6] Pi, M., Kapoor, K., Ye, R., Nishimoto, S. K., Smith, J. C., Baudry, J., \& Quarles, L. D. (2016). Evidence for Osteocalcin Binding and Activation of GPRC6A in $\beta$-Cells. Endocrinology, 157(5), 1866-1880. https://doi. org/10.1210/en.2015-2010

[7] Liu, D. M., Guo, X. Z., Tong, H. J., Tao, B., Sun, L. H., Zhao, H. Y. Ning, G., \& Liu, J. M. (2015). Association between osteocalcin and glucose metabolism: a meta-analysis. Osteoporosis International, 26(12) 2823-2833. https://doi.org/10.1007/s00198-015-3197-8

[8] Ling, Y., Gao, X., Lin, H., Ma, H., Pan, B., \& Gao, J. (2016). A common polymorphism rs 1800247 in osteocalcin gene is associated with hypertension and diastolic blood pressure levels: the Shanghai Changfeng study. Journal of Human Hypertension, 30(11), 679-684. https://doi. org/10.1038/hh. 2016.16

[9] Chumachenko, Y. D., Harbuzova, V. Y., \& Ataman, A. V. (2019). Association Study between BGLAP Gene HindlII Polymorphism and Type 2 Diabetes Mellitus Development in Ukrainian Population. Journal of Diabetes Research, 2019, Article 9302636. https://doi. org/10.1155/2019/9302636

[10] Darwish, L., Nguyen, M. M., Saleem, M., Eakin, K. A., Herrmann, N. Sugamori, K. S., Oh, P. I., Yang, P., Mitchell, J., Lanctôt, K. L., \& Swardfager, W. (2019). Lower serum osteocalcin concentrations in patients with type 2 diabetes and relationships with vascular risk factors among patients with coronary artery disease. Journal of Diabetes and its Complications, 33(5), 390-397. https://doi.org/10.1016/.j.jiacomp.2019.01.003

111] Riquelme-Gallego, B, García-Molina, L, Cano-lbáñez, N., Sánchez-Delgado, G., Andújar-Vera, F., García-Fontana, C., González-Salvatierra, S., García-Recio, E., Martínez-Ruiz, V., Bueno-Cavanillas, A. Muñoz-Torres, M., \& García-Fontana, B. (2020). Circulating Undercarboxylated Osteocalcin as Estimator of Cardiovascular and Type 2 Diabetes Risk in Metabolic Syndrome Patients. Scientific Reports, 10(1), Article 1840. https://doi.org/10.1038/s41598-020-58760-7

[12] Kunutsor, S. K., Apekey, T. A., \& Laukkanen, J. A. (2015). Association of serum total osteocalcin with type 2 diabetes and intermediate metabolic phenotypes: systematic review and meta-analysis of observational evidence. European Journal of Epidemiology, 30(8), 599-614. https:ll doi.org/10.1007/s10654-015-0058-X

[13] Das, S. K., Sharma, N. K., \& Elbein, S. C. (2010). Analysis of osteocalcin as a candidate gene for type 2 diabetes (T2D) and intermediate traits in Caucasians and African Americans. Disease Markers, 28(5), 281-286. https://doi.org/10.3233/DMA-2010-0701

[14] Lin, X., Onda, D. A., Yang, C. H., Lewis, J. R., Levinger, I., \& Loh, K. (2020). Roles of bone-derived hormones in type 2 diabetes and cardiovascular pathophysiology. Molecular Metabolism, 40, Article 101040. https://doi.org/10.1016/i.molmet.2020.101040

[15] Xu, Y., Ma, X., Xiong, Q., Hu, X., Zhang, X., Yuan, Y., \& Bao, Y. (2018). Association between serum osteocalcin level and blood pressure in a Chinese population. Blood Pressure, 27(2), 106-111. https://doi.org/10.1080/08037051.2017.1408005 